\title{
Tinjauan Filosofis tentang Kebutuhan dan Tanggung Jawab Peserta Didik
}

\author{
Imam Syafi'i \\ UIN Sunan Ampel Surabaya \\ Email: imamsyafii.iwa@gmail.com
}

\begin{abstract}
Abstrak
Dalam pendidikan, peserta didik merupakan individu yang memiliki potensi untuk berkembang. Dalam perkembangan peserta didik, secara hakiki memiliki kebutuhan yang harus dipenuhi dan tanggungjawab yang harus diemban. Penelitian pustaka ini berupaya untuk menganalisis pemenuhan kebutuhan dan tanggung jawab anak didik yang merupakan instrumen penting bagi perkembangan karakternya. Temuan penelitian ini mengungkapkan bahwa peserta didik memiliki beragam potensi yang perlu dikembangkan oleh guru melalui proses pendidikan. Kebutuhan peserta didik yang harus dipenuhi di antaranya: kebutuhan fisik, kebutuhan sosial, kebutuhan mendapatkan status, kebutuhan mandiri, kebutuhan berprestasi, kebutuhan kasih sayang, kebutuhan untuk saling memberikan masukan, dan kebutuhan beragama. Sementara tanggung jawab peserta didik adalah sebagai berikut: Pertama, harus mensucikan jiwanya dari kotoran dan penyakit jiwa. Kedua, selalu konsentrasi terhadap ilmu yang sedang dipelajarinya dan mengurangi kesibukan duniawi. Ketiga, menuntut ilmu secara bertahap dengan penuh kesabaran dan ketabahan. Keempat, mengetahui nilai ilmu yang dipelajarinya. Kelima, selalu berusaha untuk mendapatkan ridha dari guru dan dan selalu menghormati gurunya. Pemenuhan kebutuhan dan tanggung jawab peserta didik tersebut merupakan bagian dari proses anak didik untuk memiliki akhlak yang mulia. Akhlak yang mulia merupakan modal utama untuk mencari pengetahuan dan mencapai keberhasilan.
\end{abstract}

Kata Kunci: Peserta Didik, Filsafat Pendidikan, Karakter

\section{Pendahuluan}

Dalam setiap lini kehidupan, pendidikan merupakan suatu hal yang urgen. Sebagai alat untuk membentuk manusia ideal, maka pendidikan memiliki peranan penting dalam kehidupan umat manusia, sehingga pendidikan tidak akan pernah terlepas dari kehidupan kita sehari-hari. Dalam kegiatan dapat dikatakan sebagai pendidikan jika terdapat beberapa komponen yang harus dipenuhi, yakni tujuan pendidikan, pendidik dan peserta didik, kurikulum pendidikan, dan metode pendidikan serta konteks pendidikan. 
Peserta didik sebagai salah satu komponen pendidikan menempati posisi yang menentukan dalam sebuah interaksi pembelajaran. Dalam pendidikan, peserta didik merupakan individu yang memiliki potensi untuk berkembang, dan mereka berusaha mengembangkan potensinya itu melalui proses pendidikan pada jalur dan jenis pendidikan tertentu. ${ }^{1}$ Dalam perkembangan peserta didik ini, secara hakiki memiliki kebutuhan-kebutuhan yang harus dipenuhi. Pemenuhan kebutuhan peserta didik tumbuh dan berkembang mencapai kematangan fisik dan psikis. $^{2}$

Oleh karena itu, guru sebagai pendidik kehadirannya tidak mempunyai arti, tanpa kehadiran peserta didik sebagai subjek pendidikan. Dengan demikian dapat dikatakan bahwa peserta didik merupakan kunci yang menentukan terjadinya interaksi edukatif. Dari sinilah yang menyebabkan kajian tentang peserta didik tetap eksis dan dianggap perlu untuk dilakukan, terutama yang berkaitan dengan hakekat peserta didik, tugas dan tanggung jawab peserta didik dan karakter peserta didik yang baik.

Sementara dorongan dan motivasi dari orang lain sangat menentukan akan suksesnya pendidikan anak. Khususnya dorongan dan motivasi bahkan bantuan dari orang yang lebih dewasa, baik dari guru itu sendiri maupun dari orang tua peserta didik. Hal yang demikian dapat

1 Peserta didik merupakan "Raw Material" (Bahan Mentah) dalam proses transformasi dan internalisasi, menepati posisi yang sangat penting untuk melihat signifikasinya dalam menemukan keberhasilan sebuah proses. Peserta didik adalah makhluk individu yang mempunyai kepribadian dengan ciri-ciri yang khas yang sesuai dengan pertumbuhan dan perkembangannya. Pertumbuhan dan perkembangan peserta didik dipengaruhi oleh lingkungan dimana ia berada. Lihat, M. Ramli, "Hakikat Pendidik dan Peserta Didik", Tarbiyah Islamiyah, Vol. 5, No. 1, (Januari-Juni 2015).

${ }^{2}$ Setiap peserta didik memiliki eksistensi atau kehadiran dalam sebuah lingkungan, seperti halnya sekolah, keluarga, pesantren bahkan dalam lingkungan masyarakat. Dalam proses ini peserta didik akan banyak sekali menerima bantuan yang mungkin tidak disadarinya. Adapun esensi manusia itu adalah sebagai makhluk ciptaan Allah bukanlah makhluk yang ada dan bereksitensi dengan sendirinya, dan di dalam diri manusia itu terdapat beberapa unsur yaitu unsur al-jism dan al-ruh atau fisik dan psikis. Sehingga, dapat disimpulkan bahwa esensi peserta didik tidak akan bisa untuk diketahui jika mereka tidak mengetahui hakikat atau esensi dari manusia itu sendiri. Kemampuan untuk itu tentu tidak hanya bisa berdiri sendiri tapi haruslah ada bantuan dari orang dewasa, atau bahasa yang lebih teknis pendidikan. Dengan pendidikan inilah peserta didik ditempa, baik terhadap jasmani maupun rohaninya. Baca, Musaddad Harahap, "Esensi Peserta Didik dalam Perspektif Pendidikan Islam", Jurnal Al-Thariqah, Vol. 1, No. 2 (Desember 2016).

El-Banat Vol. 9. No.2 (2019) 283 
disadari bahwa peserta didik adalah anak yang tengah membutuhkan pengetahuan atau ilmu, bimbingan dan pengarahan. Akan tetapi sebuah kesuksesan tersebut akan sulit tercapai jika tidak didukung oleh diri pesrta didik itu sendiri. Oleh karena itu, peserta didik ketika menempuh suatu pendidikan agar supaya dapat berhasil dan sukses, maka peserta didik harus ditanamkan sikap tawadhu', jiwa yang bersih dari perbuatanperbuatan tercela, mempunyai ketulusan hati serta kesabaran dalam bertindak.

\section{Hakikat Peserta Didik}

Menurut bahasa Indonesia, terdapat tiga sebutan untuk anak didik yaitu murid, pelajar atau peserta didik. Sebutan murid bersifat umum sama umumnya dengan sebutan pelajar dan peserta didik. Sementara istilah murid biasanya merupakan sebutan khas ala pesantren dan terdapat pengaruh dalam agama Islam. ${ }^{3}$ Berbeda dalam bahasa arab dikenal dengan tiga istilah yang sering digunakan untuk menunjukkan pada anak didik. dari ketiga istilah tersebut yakni: Murid, (berasal dari kata aradayuridu-iradatan). Adapun isim fa'il dari arada adalah muridan yang memiliki makna orang yang menginginkan, karena seorang murid adalah orang yang menginginkan untuk mendapatkan ilmu pengetahuan, keterampilan, pengalaman, dan kepribadian yang baik untuk mempersiapkan sebagai bekal hidupnya agar menjadi orang yang sukses baik di dunia maupun di akhirat. ${ }^{4}$ Sementara istilah lainnya yakni: Tilmidz jamaknya Talamidz yang berarti murid, dan Thalib al-'Ilm yang menuntut ilmu, pelajar atau mahasiswa.

Ketiga istilah tersebut seluruhnya mengacu kepada seseorang yang sedang menempuh pendidikan. Dengan demikian, dapat diketahui bahwa perbedaannya hanya terletak pada penggunaannya. Misalnya di sekolah yang tingkatannya rendah seperti Sekolah Dasar dengan menggunakan istilah murid dan Tilmidz. Sedangkan di sekolah yang tingkatannya lebih tinggi seperti Sekolah Lanjutan Tingkat Pertama, Sekolah Lanjutan Tingkat Atas dan Perguruan Tinggi dengan menggunakan istilah Thalib al-Ilm. ${ }^{5}$ Berbeda dengan istilah dalam bahasa Inggris, student merupakan

${ }^{3}$ Ahmad Tafsir, Filsafat Pendidikan Islami: Integrasi Jasmani, Rohani dan Kalbu Memanusiakan Manusia (Bandung: Remaja Rosda Karya, 2010), 165.

4 Abuddin Nata, Perspektif Islam tentang Pola Hubungan Guru-Murid: Studi Pemikiran Tasawuf al-Ghazali (Jakarta: Raja Grafindo Persada, 2001), 49.

5 Abuddin Nata, Filsafat Pendidikan Islam (Jakarta: Logos Wacana Ilmu, 1997), 79-82. 
sebutan yang biasa dikenal dalam untuk sebutan peserta didik. ${ }^{6}$ Menurut kandungan di dalam Undang Undang RI No. 20 Tahun 2003 pasal 1 ayat 4 tentang sistem Pendidikan Nasional, dikatakan bahwasannya, peserta didik adalah anggota masyarakat yang berusaha mengembangkan dirinya melalui proses pendidikan pada jalur jenjang dan jenis pendidikan tertentu. ${ }^{7}$ Oleh karena itu, dari penegasan undang-undang ini, sudah selayaknya bahwa seluruh anggota masyarakat di negeri ini berhak untuk mendapat pendidikan yang mumpuni.

Dari beberapa definisi di atas, maka peserta didik dapat dicirikan sebagai orang yang sedang mencari dan memerlukan pengetahuan atau ilmu, bimbingan dan pengarahan. ${ }^{8}$ Dengan demikian yang dimaksud dengan peserta didik adalah salah satu komponen masyarakat yang membutuhkan pendidikan dari komponen lain, terlebih lagi bantuan dan motivasi dari orang yang lebih dewasa, seperti guru, orang tua.

Istilah-istilah di atas patut untuk direnungkan terutama kaitannya dengan SISDIKNAS kita. Artinya ketika disebutkan peserta didik apa berarti istilah yang lain dianggap telah terwakili di dalamnya atau sebaliknya, artinya penggunaan istilah ini sangat umum. Logika berpikirnya kelihatannya begitu, walaupun memang secara konten pembelajarannya satu sama lain berbeda tapi prinsip-prinsip dasarnya secara umum tidak berbeda, yaitu sama-sama pembelajar yang terikat oleh regulasi-regulasi yang ada. Hal inilah yang membuat pemerintah membuat formulasi bahwa peserta didik adalah anggota masyarakat yang berusaha mengembangkan potensi. ${ }^{9}$

Dalam konteks kehidupan masyarakat, pendidikan diharapkan dapat menyentuh semua jenis dan kalangan manusia. Dari kalangan manusia atau masyarakat yang banyak dijadikan fokus subjek pendidikan adalah terdapat pada dunia anak, karena anak merupakan bahan mentah dalam proses pendidikan. Untuk itu, anak dalam dunia pendidikan diistilahkan dengan peserta didik. Terdapat beberapa hal yang membedakan peserta didik dengan komponen-komponen lain dalam pendidikan, sebab komponen lain dapat dirumuskan dan disusun sesuai dengan keadaan dan kebutuhan yang ada. Berbeda dengan peserta didik

${ }^{6}$ Jhon M. Echol \& Hasan Syadily, Kamus Inggris Indonesia (Jakarta: Gramedia, tt.), 563.

${ }^{7}$ Ramayulis, Ilmu Pendidikan Islam (Jakarta: Kalam Mulia, 2002), 77.

${ }^{8}$ Nata, Filsafat Pendidikan Islam, 80.

${ }^{9}$ Musaddad Harahap, "Esensi Peserta Didik dalam Perspektif Pendidikan Islam", Jurnal Al-Thariqah, Vol. 1, No. 2, (Desember 2016).

El-Banat Vol. 9. No.2 (2019) 285 
pada dasarnya sudah mempunyai kemampuan atau potensi dasar yang dimiliki pada masing-masing anak. ${ }^{10}$

Hal yang berbeda dengan pernyataan di atas, bahwa dalam paradigma pendidikan Islam, bahwa peserta didik merupakan anak yang belum mencapai taraf kematangan dan memiliki potensi dasar dan perlu untuk dikembangkan oleh guru melalui proses pendidikan. oleh karena itu, potensi dasar yang dimiliki oleh setiap peserta didik tidak akan berkembang secara maksimal tanpa melalui proses pendidikan. ${ }^{11} \mathrm{Hal}$ yang demikian sebagaimana dalam teori konvergensi yang mengatakan bahwa bakat yang dibawa pada waktu lahir tidak akan berkembang dengan baik tanpa adanya proses pengalaman. Dari pengalaman ini bisa didapat melalui dua kategori yakni: pengalaman dengan lingkungannya atau pengalaman melalui pendidikan. Kedua-duanya mempunyai pengaruh yang sama besar bagi pertumbuhan dan perkembangan kemampuan anak. $^{12}$

Berbeda dengan teori konvergensi, teori empirisme menganggap bahwa perkembangan potensi yang dimiliki peserta didik hanya dipengaruhi oleh lingkungan, sehingga menurut teori ini bakat pembawaan tidak mempunyai pengaruh sama sekali dalam proses perkembangan anak. ${ }^{13}$ Oleh karena itu, dalam aliran ini, pengaruh empiris yang diperoleh dari lingkungan berpengaruh besar terhadap perkembangan anak. Guru sebagai faktor luar memegang peranan yang sangat penting, sebab seorang guru dalam hal ini harus menyediakan lingkungan pendidikan bagi anak, dan anak akan menerima pendidikan sebagai pengalaman, baik bersifat sosial ataupun kultural. ${ }^{14}$ Pengalaman

${ }^{10}$ Pendidikan Islam memandang peserta didik berperan sebagai objek sekaligus subjek dalam prosesnya. Sehingga, peserta didik harus mengetahui kewajiban dan tugasnya agar dapat mencapai tujuan yang diinginkan. Oleh karena itu agar proses pendidikan berhasil maka antara pendidik dan peserta didik harus bisa saling memahami dengan segala karakteristik masing-masing. Baca, Lailatul Maghfiroh, "Hakikat Pendidik dan Peserta Didik dalam Pendidikan Islam", MIDA : Jurnal Pendidikan Dasar Islam, Vol 2 No 2 (2019).

${ }^{11}$ Toto Suhartono, Filsafat Pendidikan Islam (Jogjakarta: Ar-Ruzz Media, 2011), 119.

12 M. Jindar Wahyudi, Nalar Pendidikan Qur'ani (Yogyakarta: Apeiron Philotes, 2006), 21.

13 Muhibbin Syah, Psikologi Pendidikan dengan Pendekatan Baru (Bandung: Remaja Rosda Karya, 2005), 44.

${ }^{14}$ Lihat, Nia Indah Purnamasari, "Komparasi Konsep Sosiokulturalisme dalam Pendidikan: Perspektif Barat dan Islam", El-Banat: Jurnal Pemikiran dan Pendidikan Islam, Vol. 9, no. 2 (2019). 
tersebut akan membantu peserta didik dalam mengembangkan potensi yang dimiliki oleh peserta didik.

Menurut Hasan Basri dalam bukunya Filsafat Pendidikan Islam mengemukakan bahwa, hakikat peserta didik dalam perspektif pendidikan Islam terdiri dari beberapa macam di antaranya: (1) anak didik merupakan darah daging sendiri, dalam keluarga orang tua merupakan pendidik dan semua darah dagingnya adalah anak didiknya, (2) Peserta didik adalah semua anak yang berada dalam bimbingan pendidik baik di lembaga formal, informal maupun non formal. ${ }^{15}$ Sementara dalam teori Nativisme perkembangan potensi anak itu hanya ditentukan oleh bakat bawaan yang dimilikinya, sehingga pendidikan dalam pandangan teori ini tidak mempunyai peran dalam mengembangkan potensi anak itu sendiri. ${ }^{16}$

Senada dengan pendapat di atas, Samsul Nizar dalam Toto Suharto $^{17}$ menyebutkan terdapat beberapa definisi mengenai hakikat peserta didik sebagai berikut: (1) Peserta didik bukan miniatur orang dewasa, akan tetapi ia memiliki dunianya sendiri. Hal yang demikian perlu dipahami, agar supaya perlakuan terhadap anak dalam proses pendidikannya tidak disamakan dengan pendidikan orang yang sudah dewasa. Baik dalam aspek metode mengajar, materi yang akan diajarkan, sumber bahan yang digunakan, (2) Peserta didik merupakan manusia yang memiliki diferensiasi periodesasi perkembangan dan pertumbuhan. Pemahaman ini cukup perlu untuk diketahui agar aktivitas pendidikan Islam disesuaikan dengan tingkat pertumbuhan dan perkembangan yang pada umumnya dilalui oleh setiap peserta didik. Hal ini sangat beralasan, karena kadar kemampuan peserta didik ditentukan oleh faktor usia dan periode perkembangan atau pertumbuhan potensi yang dimilikinya, (3) Peserta didik merupakan manusia yang memiliki kebutuhan, baik yang menyangkut kebutuhan jasmani maupun rohani yang harus dipenuhi. Di antara kebutuhan jasmani dan rohani tersebut adalah kebutuhan biologis, kasih sayang, rasa aman, harga diri, realisasi diri, dan lain sebagainya. Dari kesemuanya kebutuhan itu penting dipahami oleh guru agar tugastugas dan proses kependidikannya dapat berjalan dengan efektif dan efisien, (4) Peserta didik merupakan makhluk ciptaan Allah yang memiliki perbedaan individual, baik yang disebabkan oleh faktor pembawaan maupun lingkungan di mana ia berada. Pemahaman tentang differensiasi individual peserta didik sangat penting untuk

\footnotetext{
${ }^{15}$ Hasan Basri, Filsafat Pendidikan Islam (Bandung: Pustaka Setia, 2009), 88.

${ }^{16}$ Mansur Isna, Diskursus Pendidikan Islam (Yogyakarta: Global Pustaka, 2001), 157.

${ }^{17}$ Ibid., 120-121.
} 
dipahami oleh seorang guru. Hal ini disebabkan karena menyangkut bagaimana pendekatan yang perlu dilakukan oleh seorang guru dalam menghadapi berbagai macam sikap dan perbedaan tersebut dalam suasana yang dinamis, tanpa harus mengorbankan kepentingan salah satu pihak atau golongan, (5) Peserta didik merupakan resultan dari dua unsur utama, yakni Unsur jasmani dan unsur rohani. Unsur jasmani memiliki daya fisik yang menghendaki latihan dan pembiasaan yang dilakukan melalui proses pendidikan. Sementara unsur rohaniyyah memiliki dua daya, yaitu daya akal dan daya rasa. Untuk mempertajam daya akal, maka proses pendidikan hendaknya diarahkan untuk mengasah daya intelektualitasnya melalui ilmu-ilmu rasional. Adapun untuk mempertajam daya rasa dapat dilakukan melalui pendidikan akhlak dan pendidikan ibadah. Konsep ini bermakna bahwa suatu proses pendidikan Islam hendaknya dilakukan dengan memandang peserta didik secara utuh. Pada dataran praktis, pendidikan Islam tidak hanya mengutamakan pendidikan salah satu aspek saja, melainkan kedua aspek secara integral dan harmonis. Jika tidak demikian, maka pendidikan tidak akan mampu menciptakan out put yang memiliki kepribadian utuh, akan tetapi justru sebaliknya yaitu kepribadian yang ambigu. Jika fenomena ini terjadi dalam praktik pendidikan Islam, maka upaya untuk menciptakan insan kamil akan hanya sebuah mimpi belaka, dan (6) Peserta didik merupakan manusia yang memiliki potensi (fithrah) yang dapat dikembangkan dan berkembang secara dinamis. Di sini tugas seorang guru adalah membantu mengembangkan dan mengarahkan perkembangan peserta didik tersebut sesuai dengan tujuan pendidikan yang diinginkan, tanpa melepaskan tugas kemanusiaannya, baik secara vertikal maupun horizontal.

Senada dengan hal tersebut di atas, Khoiron Rosyadi juga berpendapat bahwa peserta didik adalah makhluk yang aktif dan kreatif. Setiap peserta didik memiliki aktivitas dan kreatifitas sendiri, sehingga kita tidak boleh memandang peserta didik sebagai objek pasif dalam proses pembelajaran, akan tetapi peserta didik merupakan subjek aktif dan kreatif, yang secara selektif mampu bereaksi terhadap lingkungan masing-masing. ${ }^{18}$ Oleh karena itu, berdasarkan beberapa pendapat di atas, peserta didik dapat dikatakan sebagai anak yang belum dewasa dan memiliki sejumlah potensi (kemampuan) dasar yang masih perlu diasah dan dikembangkan.

Sedangkan hakikat peserta didik pada dasarnya perlu untuk difahami oleh seorang guru yang berfungsi sebagai landasan filosofis dalam menerapkan proses pendidikan yang tidak lagi berorientasi pada

${ }^{18}$ Khoiron Rosyadi, Pendidikan Profetik (Yogyakarta: Pustaka Pelajar, 2004), 197. 
materi pelajaran, akan tetapi proses pendidikan itu harus berorientasi pada peserta didik. Dalam proses pendidikan itu sudah berorientasi pada peserta didik, maka kedudukan peserta didik dalam proses pendidikan merupakan sebagai subjek bukan sebagai objek pendidikan, sehingga tidak ada yang dieksploitasi, dan bukan pula hubungan koersif. Dengan memandang peserta didik sebagai subjek, maka akan dapat menumbuhkan upaya untuk saling membantu demi meningkatkan kualitas antara guru dan peserta didik dalam proses pendidikannya. ${ }^{19}$

Berbeda dengan Toto Suharto, ia memposisikan peserta didik sebagai subjek pendidikan yang mengindikasikan perlunya penerapan filsafat kontruktivisme dalam pendidikan. Menurut filsafat ini, pengetahuan merupakan bentukan dari orang yang sedang belajar. Pengetahuan yang diperoleh peserta didik selama proses pembelajaran merupakan hasil kontruksinya sendiri. Proses pembelajaran yang menekankan pembentukan pengetahuan oleh peserta didik sendiri disebut pembelajaran yang kontruktivistik. Sedangkan dalam paradigma pendidikan seperti ini, antara guru dan peserta didik sama-sama melakukan proses belajar, sehingga keduanya sama-sama diposisikan sebagai subjek yang mana masing-masing berusaha menemukan pengetahuan dan mengembangkan kerangka berfikirnya sendiri. ${ }^{20}$

Dari beberapa pendapat di atas, maka dapat diambil kesimpulan bahwa peserta didik merupakan dua unsur jasmani dan rohani, unsur jasmani memiliki daya fisik yang menghendaki latihan dan pembiasaan yang dilakukan melalui proses pendidikan. Sedangkan unsur rohani memiliki daya akal hati nurani dan daya rasa. Untuk mempertajam daya akal, maka proses pendidikan hendaknya di arahkan untuk mengasah daya intelektualitasnya melalui ilmu-ilmu rasional. Adapun untuk mempertajam daya rasa dapat dilakukan melalui pendidikan akhlak dan ibadah. Konsep ini bermakna bahwa suatu proses pendidikan Islam hendaknya dilakukan dengan memandang peserta didik secara utuh. Oleh sebab itu, peserta didik harus dipahami sebagai manusia yang memiliki potensi fitrah yang dapat dikembangkan dan berkembang secara dinamis. Di sini tugas pendidik adalah membantu mengembangkan dan mengarahkan perkembangan tersebut sesuai dengan tujuan pendidikan yang diinginkan, tanpa melepaskan tugas kemanusiaanya; baik secara vertikal maupun horizontal.

\section{Kebutuhan Peserta Didik}

${ }^{19}$ Suhartono, Filsafat Pendidikan Islam, 122-123.

${ }^{20}$ Ibid., 123.

El-Banat Vol. 9. No.2 (2019) 289 
Kebutuhan manusia pada umumnya sebagaimana teori hierarki kebutuhan yang telah dikembangkan oleh Maslow bahwa manusia mempunyai tujuh kebutuhan. ${ }^{21}$ Akan tetapi yang paling dari ketujuh tersebut, terdapat lima kebutuhan yang dapat membentuk tingkatantingkatan atau disebut juga hierarki dari yang mudah hingga yang sulit untuk dicapai. Motivasi manusia sangat dipengaruhi oleh kebutuhan mendasar yang harus dipenuhi. Menurut Maslow, pemenuhan yang paling penting yang harus didahulukan kemudian meningkat ke yang tidak terlalu penting. Untuk dapat merasakan nikmat suatu tingkat kebutuhan perlu dipuaskan dahulu, setelah itu kebutuhan yang berada pada tingkat di atasnya. ${ }^{22}$

Lima dasar kebutuhan Maslow ini disusun berdasarkan kebutuhan yang paling penting hingga yang tidak terlalu krusial yakni: (1) Kebutuhan Fisiologis (Phisiological needs). Contohnya adalah: sandang (pakaian), pangan (makanan), papan (rumah), dan kebutuhan biologis seperti: buang air besar, buang air kecil dan bernafas, (2) Kebutuhan keamanan dan keselamatan (safety needs). Contohnya adalah: bebas dari penjajahan, bebas dari ancaman, bebas dari rasa sakit dan bebas dari terror, (3) Kebutuhan social atau kebutuhan menjadi milik dan dicintai (sense of belongingness and love), contohnya adalah: memiliki teman, memiliki keluarga dan kebutuhan cinta dari lawan jenis, (4) Kebutuhan penghargaan (esteem needs). Contohnya: pujian, piagam, tanda jasa, hadiah dan sebagainnya, dan (5) Kebutuhan Aktualisasi Diri (Self Fulfillment) yaitu kebutuhan dan keinginan untuk bertindak sesuka hati sesuai dengan bakat dan minatnya. ${ }^{23}$

Terasa sangat menarik jika kita mengetahui tentang kebutuhan manusia di atas. Oleh karena itu setelah kita mengetahui akan kebutuhan manusia, baru akan penulis uraikan tentang kebutuhan peserta didik. Berbagai varian terkait dengan kebutuhan yang dimiliki peserta didik itu, dan pemenuhan kebutuhan ini merupakan syarat yang krusial bagi perkembangan pribadi yang sehat untuk peserta didik. Kebutuhan peserta didik yang harus dipenuhi di antaranya sebagai berikut:

Pertama, kebutuhan fisik, seperti kebutuhan biologis (kesehatan). Setiap manusia yang hidup pasti menginginkan hidup sehat, siapa yang

21 Muhammad Thobroni \& Arif Mustofa, Belajar \& Pembelajaran: Pengembangan Wacana dan Praktik Pembelajaran dalam Pembangunan Nasional (Jogjakarta: Ar-Ruzz Media, 2011), 166.

22 Patricia Wallace, Jeffrey H. Goldstein, and Peter Nathan, Introduction to Psychology (Dubuque, IA: Wm. C. Brown, 2007), 277.

23 Sarlito W. Sarwono, Berkenalan dengan Aliran-aliran dan Tokoh-tokoh Psikologi (Jakarta: Bulan Bintang, 2002), 176-178. 
hidupnya tidak mau sehat? Kebutuhan untuk tumbuh sehat merupakan keinginan semua manusia. Dalam hal ini tentu pola makan harus mendapatkan makan yang bergizi, papan yang sehat, udara segar, tidur atau istirahat, olah raga dan rekreasi. Pemenuhan kebutuhan fisik ini merupakan modal dasar bagi diperolehnya otak yang sehat dan cerdas.

Untuk mendapatkan generasi sehat yang mempunyai kualitas terbaik, maka makanan sehat menjadi poin penting yang harus diperhatikan untuk diberikan pada setiap manusia. Sebab dengan makanan yang sehat, manusia diharapkan dapat menciptakan karya terbaiknya melalui pengoptimalan produktifitas dari aktivitas mereka. Untuk memenuhi kebutuhan gizi bagi tubuh, makanan tidak selalu harus mahal karena esensi makanan sehat tidak bisa dilihat semata dari mahal tidaknya sebuah makanan tersebut, tetapi mampu tidak kita menjaga kebersihan

Selain dari itu, makanan yang layak dikonsumsi manusia adalah makanan yang mampu memenuhi asupan gizi yang dibutuhkan tubuh serta umumnya justru terbuat dari bahan makanan alami dan tidak tercampur dan melibatkan proses kimia. Kebutuhan tubuh sendiri ini biasanya meliputi empat sehat lima sempurna yang meliputi karbohidrat, protein, mineral, vitamin, dan susu. Jika manusia telah mendapatkan kandungan gizi tersebut, mereka bisa disebut telah mendapatkan makanan sehat. Jika tidak memperhatikan kesehatan, maka akan mudah terkena penyakit, hal ini harus ditangani dengan cepat karena kesehatan sangat mempengaruhi pertumbuhan fisiknya. ${ }^{24}$

Senada dengan hal di atas, Ibn Sina mengemukakan bahwa pemenuhan kebutuhan dan pembinaan fisik yang berupa olahraga, makan, minum, tidur, dan menjaga kebersihan merupakan modal dasar bagi diperolehnya otak yang sehat. ${ }^{25}$ Di sampping itu, untuk mencapai fisik yang prima dengan cara istirahat yang cukup, konsumsi makanan yang bergizi serta menjauhi makan minum yang dapat menjadikan dirinya mabuk. ${ }^{26}$ Kedua, kebutuhan sosial seorang anak adalah hal-hal yang berhubungan dengan tindakan-tindakan dalam kaitannya dengan orang lain seperti pertemanan dengan teman sebaya, komunikasi dengan orang dewasa dan orang tua. Dari kebutuhan sosial inilah yang juga mampu menentukan posisi dan prestasi yang diperoleh peserta didik di tengah-tengah masyarakat. ${ }^{27}$

${ }^{24}$ Ramayulis, Ilmu Pendidikan Islam, 78.

${ }^{25}$ Abuddin Nata, Pemikiran Para Tokoh Pendidikan Islam (Jakarta: Raja grafindo Persada, 2000).

${ }^{26}$ Nata, Filsafat Pendidikan Islam , 82.

${ }^{27}$ Ramayulis, Ilmu Pendidikan Islam, 78. 
Ketiga, kebutuhan ingin disayangi dan dicintai. Setiap orang tua mengetahui bahwa anak membutuhkan kasih sayang. Oleh karena itu yang perlu diperhatikan adalah ukuran kebutuhan setiap anak berbeda antara yang satu dengan yang lainnya. Anak yang satu membutuhkan kasih sayang yang lebih dari yang lain, walaupun tidak dapat mengekspresikan dengan jelas. Anak yang normal mempunyai kebutuhan kasih sayang yang berbeda dengan anak yang cacat atau kurang normal. Kasih sayang sebagai kebutuhan yang mendasar bagi anak, akan mempengaruhi seluruh perkembangan hidupnya. ${ }^{28}$ Oleh karena itu diperlukan kasih sayang yang murni dan tulus dari orang tua. Di samping itu pula terdapat kasih sayang yang tidak mementingkan diri sendiri dan tanpa syarat. Karena itulah setiap orang tua harus selalu mengingat bahwa sangat mungkin bagi orang tua memberikan kasih dengan mengharapkan sesuatu dari anak. Orang tua yang memberikan kasih sayang sebagai alat agar anak melakukan kehendak orang tua, cenderung akan memanipulasi atau mendikte anak.

Jika kita lihat anak-anak yang mendapatkan kasih sayang yang cukup dari orang tuanya akan bertumbuh lebih sehat secara emosi, sosial, dan kerohanian, sehingga anak yang demikian akan merasa bahwa dirinya merasa penting, berharga dan patut dicintai. Hal yang demikian akan membuat anak menjadi lebih leluasa mengembangkan dirinya, merasa diterima seutuhnya, baik di dalam keluarganya sendiri maupun di masyarakat, dan pada akhirnya nanti kelak lebih mudah pula untuk saling mengasihi mengasihi pada orang lain.

Keempat, kebutuhan akan beragama. ${ }^{29}$ Kebutuhan akan beragama untuk peserta didik harus lebih ditekankan, karena ajaran agama yang

${ }^{28}$ Kebutuhan rasa kasih sayang dan kebutuhan rasa harga diri, menghargai dan menyayangi adalah dua ekspresi emosi yang selalu patut ditunjukkan oleh orang tua kepada anaknya dan oleh guru kepada siswanya. Dua ekspresi emosi ini amat tulus diberi kan oleh orang tua kepada buah hatinya, perasaan sayang dan dihargai yang diterima oleh anak membuat mereka selalu bersemangat untuk melaksanakan aktivitas yang tiada henti-hentinya dalam menjalani proses pertumbuhan mereka. Perlu diketahui bahwa semua anak mempunyai harga diri sebagaimana orang dewasa. Mereka tidak ingin harga dirinya diinjak-injak walaupun oleh orang tuanya sendiri atau oleh gurunya. Mereka tetap ingin menjaga harga dirinya walaupun harus dengan cara melawan. Inilah hakikat manusia, yang tidak hanya berlaku pada orang dewasa saja, tetapi juga untuk anak-anak. Baca, Abd. Azis, "Humanisme dalam Pendidikan Islam: Konsepsi Pendidikan Ramah Anak", Jurnal Pendidikan Agama Islam (Journal of Islamic Education Studies), Vol. 5, No. 1 (2017).

${ }^{29}$ Ramayulis, Ilmu Pendidikan Islam,78-80. 
sudah diyakini dan diamalkan oleh peserta didik, akan mampu mewarnai seluruh aspek kehidupannya, sehingga ketika seorang guru tidak mampu memenuhi kebutuhan terhadap agama ini, maka seorang guru tidak mampu pula meraih perkembangan peserta didiknya secara maksimal sebagaimana yang diharapkan. ${ }^{30}$

Dari uraian di atas dapat dipahami bahwa peserta didik memiliki berbagai kebutuhan, baik kebutuhan yang bersifat lahiriah maupun kebutuhan rohaniah. Untuk pengembangn kedua aspek tersebbut diperlukan ilmu dan pendidik yang sesuai dengan kebutuhan peserta didik tersebut. Sehingga pengembanagn potensi yang ada pada diri pendidik dapat tercapai.

\section{Tanggung Jawab Peserta Didik}

Sesuai dengan karakter dasarnya, ilmu itu datangnya dari Allah dan karenanya ia merupakan al-nur atau cahaya kebenaran yang akan menerangi kehidupan para pencarinya. Sebagai al-haq, Allah Maha Suci, dan kesuciannya hanya bisa dihampiri oleh yang suci pula. Karenanya, sifat utama dan pertama yang harus dimiliki peserta didik adalah mensucikan diri atau jiwanya (tazkiyah) sebelum menuntut ilmu pengetahuan. Karena maksiat hanya akan mengotori jasmani, akal, jiwa dan hati manusia, sehingga membuatnya sulit dan terhijab dari cahaya, kebenaran, atau hidayah Allah. ${ }^{31}$

Sejalan dengan penjelasan ini Al-Attas mengemukakan bahwa sebetulnya orang-orang muslim sepakat bahwa semua ilmu itu datangnya dari Allah. Di mana kedatangannya kepada fakultas-fakultas jiwa serta indera yang menerima dan menafsirkannya tidaklah sama. ${ }^{32}$ Artinya pensucian jiwa dan jasmani harus betul-betul diperioritaskan karena ilmu adalah milik Allah dan dari Dialah asalnya. Memang manusia dalam menerima dan menafsrikannya tidaklah sama, namun itulah yang menjadi tugas pendidikan Islam agar kedua dimensi yang telah disepakati beserta subtansi yang terdapat di dalamnya tetap terpelihara dari berbagai gangguan dan noda yang akan membuat daya-dayanya terkikis dan melemah.

Agar pelaksanaan proses pendidikan Islam dapat mencapai tujuan yang dikehendaki untuk menjadikan peserta didikinsane kamil, maka setiap peserta didik hendaknya senantiasa menyadari tugas dan tanggung

${ }^{30}$ Ibid, 81-82.

${ }^{31}$ Zainuddin dan Mohd. Nasir, Filsafat Pendidikan Islam (Bandung: Citapustaka Media Perintis, 2010), 111-113.

32 Syed Muhammad Naquib al-Attas, Konsep Pendidikan Dalam Islam, Terj. Haidar Bagir (Bandung: Mizan, 1990), 42. 
jawabnya. Seperti dikemukakan oleh Al-Abrasyi sebagaimana dikutif Al Rasyidin, bahwa di antara tugas-tugas dan tanggung jawab peserta didik itu antara lain: (1) Sebelum memulai aktivitas pembelajaran, peserta didik harus terlebih dahulu membersihkan hatinya dari sifat yang buruk, karena belajarmengajar itu merupakan ibadah dan ibadah harus dilakukan dengan hati dan jasmani yang bersih; (2) Peserta didik belajar harus dengan maksud mengisi jiwanya dengan berbagai keutamaan untuk mendekatkan diri kepada Allah; (3) Bersedia mencari ilmu ke berbagai tempat yang jauh sekalipun, meskipun harus meninggalkan daerah tempat kelahiran atau tanah air, keluarga, saudara atau bahkan ayah dan ibu dan sebagainya; (4) Tidak terlalu sering menukar guru, dan hendaklah berpikir panjang sebelum menukar guru; (5) Hendaklah menghormati guru, memuliakannya, dan mengagungkannya karena Allah serta berupaya menyenangkan hatinya dengan cara yang baik dan diridhai oleh Allah; (6) Jangan merepotkan guru, jangan berjalan di hadapannya, jangan duduk di tempat duduknya, dan jangan mulai berbicara sebelum diizinkannya; (7) Jangan membukakan rahasia kepada guru atau meminta guru membukakan rahasia, dan jangan pula menipunya; (8) Bersungguhsungguh dan tekun dalam belajar; (9) Saling bersaudara dan mencintai antara sesama peserta didik; (10) Peserta didik harus terlebih dahulu memberi salam kepada guru dan mengurangi percakapan di hadapannya; dan (11) Peserta didik hendaknya senantiasa mengulangi pelajaran, baik di waktu senja dan menjelang subuh atau antara waktu Isya' dan makan sahur. ${ }^{33}$ (Al Rasyidin, 2012: 153-154).

Tanggung jawab utama peserta didik adalah belajar, menuntut ilmu serta mengamalkannya dalam kehidupan sehari-hari. hal ini sebagaimana di kemukakan oleh Syaiful Bahri Djamarah, yang dikutip oleh Hasan Basri mengatakan bahwa peserta didik yang memiliki konsentrasi penuh dalam belajar itulah peserta didik yang mengerti tugasnya dalam belajar. Oleh karena itu jika dalam belajar peserta didik tidak dapat konsentrasi, maka dia tidak akan mampu menyerap penjelasan yang disampaikan oleh gurunya. ${ }^{34}$

Tanda-tanda keberhasilan belajar peserta didik sebagaimana aliran kognitivisme merupakan perubahan mentalitas anak untuk menjadi lebih baik, lebih dewasa dan lebih cerdas dalam memecahkan suatu permasalahannya. ${ }^{35}$ Perubahan ini dapat diperoleh melalui pengembangan

33 Al Rasyidin, Falsafah Pendidikan Islami: Membangun Kerangka Ontologi, Epistimologi, dan Aksiologi Praktik Pendidikan (Bandung: Citapustaka Media Perintis, 2012), 153-154.

${ }^{34}$ Hasan Basri, Filsafat Pendidikan Islam (Bandung: Pustaka Setia, 2009), 89.

${ }^{35}$ Ibid. 
pada tiga ranah, yaitu: kognitif, afektif dan psikomotorik. ${ }^{36}$ Dalam tataran penerapan dari pengembangan tiga ranah tersebut maka tugas peserta didik adalah sebagai berikut:

Pertama, ketika akan melakukan proses belajar peserta didik harus mensucikan jiwanya dari kotoran dan penyakit jiwa. Sebab dalam ajaran Islam itu sendiri bahwa belajar merupakan ibadah yang menuntut adanya kebersihan hati. Seperti halnya ketika mau melaksanakan shalat, tidak sah jika tidak dalam keadaan suci dari hadats dan najis. ${ }^{37}$ hal ini sebagaimana dikemukakan al-Ghazali bahwa peserta didik yang tidak dapat mensucikan dirinya dari perbuatan maksiat, maka ia hanya akan memperoleh kemanfaatan ilmu di dunia saja sehingga di akhirat ia tidak akan mendapatkan kemanfaatan ilmu itu sendiri. Oleh karena itu, perbuatan maksiat itu merupakan racun ilmu pengetahuan yang tidak akan bermanfaat dalam kehidupan akhirat kelak. ${ }^{38}$

Kedua, Diperlukan kesungguhan serta konsentrasi terhadap ilmu yang sedang dipelajarinya dan dapat mengurangi kesibukan duniawi, sebab kesibukan itu bisa memecahkan konsentrasi pesrta didik. ${ }^{39}$ Ketiga, Menuntut ilmu itu harus dilakukan secara bertahap dengan penuh kesabaran dan ketabahan. Pada dasarnya ilmu pengetahuan itu bisa diterima dengan baik oleh peserta didik jika prosesya sesuai dengan tingkat perkembangan intelektualnya. Menurut al-Ghazali mengemukakan bahwa belajar secara bertahap bisa membantu peserta

${ }^{36}$ Hamzah B. Uno, Orientasi Baru Dalam Psikologi Pembelajaran (Jakarta: Bumi Aksara, 2010), 14.

${ }^{37}$ Ahmad Tafsir, Filsafat Pendidikan Islami: Integrasi Jasmani, Rohani dan Kalbu Memanusiakan Manusia, 166-167.

${ }^{38}$ Menurut al-Ghazali anak dilahirkan tanpa dipengaruhi oleh sifatsifat hereditas, karna faktor yang paling kuat mempengaruhi sifat anakanak adalah faktor pendidikan, lingkungan dan masyarakat. Pandangan ini memiliki kemiripan pandangan yang mengatakan bahwa anak lahir dalam kehidupan dengan akal pikirannya bagaikan lembaran putih yang bersih dari ukiran atau gambargambar. Abidin Ibnu Rusd, Pemikiran al-Ghazali Tentang Pendidikan (Yogyakarta: Pustaka Pelajar, 2009), 78.

${ }^{39}$ Menurut al Ghazali ilmu itu tidak akan memberikan sebagian dirinya kepadamu sebelum engkau memberikan seluruh dirimu kepadanya, dan jika engkau memberikan seluruh dirimu kepadanya, maka ilmupun pasti akan memberikan sebagian dirinya kepadamu. Pikiran yang terbagi-bagi untuk hal-hal yang berbeda sama halnya dengan anak sungai yang dibagi dalam beberapa cabang. Sebagian airnya diserap oleh tanah dan sebagian lagi menguap ke udara, sehingga tidak ada sisa yang digunakan untuk pertanian. Tafsir, Filsafat Pendidikan, 166-167. 
didik untuk menguasai ilmu dengan baik dan mendalam. ${ }^{40}$ Al-Ghazali berkata: "Hendaklah pelajar itu tidak memperdalam satu macam di antara berbagai macam ilmu dengan sekaligus. Tetapi hendaklah memperhatikan urutannya dan memulai dengan yang paling penting". ${ }^{41}$

Keempat, peserta didik seharusnya mengetahui nilai ilmu yang dipelajarinya. oleh karena itu setiap ilmu itu memiliki nilai dan tujuan yang berbeda, sebagaimana dikemukakan al-Ghazali bahwa seorang pelajar hendaknya tidak meninggalkan satu mata pelajaranpun dari ilmu pengetahuan yang terpuji. Selain dengan memandang pada maksud dan tujuan dari masing-masing ilmu itu. Kemudian jika ia berumur panjang, maka dipelajarinya secara mendalam. Kalau tidak, maka diambil yang lebih penting serta disempurnakan, dan dikesampingkannya ilmu yang lain. ${ }^{42}$

Kelima, Terus menerus berusaha untuk mendapatkan ridha dari guru dan dan selalu menghormati gurunya. Dengan bersifat rendah hati dan tidak sombong. Sebab ilmu itu merupakan musuh bagi pemuda yang menyombongkan diri, seperti banjir yang menjadi musuh tempat yang tinggi. dalam atian bahwa penuntut ilmu (peserta didik) tidak dapat memperoleh ilmu, kecuali dengan kerendahan diri dan mengarahkan pendengarannya kepada guru. ${ }^{43}$ Dari beberapa paparan di atas dapat dilihat bahwa al-Ghazali lebih menekankan asas kemanfaatan dalam mengkaji suatu ilmu.

Maka dengan demikian belajar bukanlah aktivitas yang mudah untuk dilakukan. Meskipun seorang peserta didik telah mendatangi sejumlah guru dan banyak membaca buku, namun hasil belajar yang baik belum tentu bisa dicapai. Belajar juga bukan hanya mengandalkan kehadiran dalam arti fisik, tetapi harus disertai dengan kemauan, kesadaran, kesabaran, dan masih banyak lagi sifat-sifat lain yang idealnya dimiliki setiap peserta didik. Dalam perspektif Islam, kepemilikan sifatsifat yang juga merupakan tugas dan tanggung jawab peserta didik itu merupakan persyaratan untuk mempermudah jalannya proses pembelajaran, berhasilnya pencapaian tujuan, berkahnya ilmu pengetahuan, dan kemampuan mengamalkan ilmu dalam kehidupan.

Dari beberapa tanggung jawab peserta didik di atas, maka tugas guru adalah mengarahkan peserta didik pada karakter idealnya. Kriteria

${ }^{40}$ Abidin Ibnu Rusn, Pemikiran al-Ghazali tentang Pendidikan, 87.

${ }^{41}$ Imam Al-Ghazali, Ilmu dan Manfaatnya, Terj. Achmad Sunarto (Surabaya: Karya Agung, 2010), 203.

${ }^{42}$ Abidin Ibnu Rusn, Pemikiran al-Ghazali tentang Pendidikan, 85.

43 Abu Hamid al-Ghazali, Ihya' 'Ulumiddin, Terj. Moh.Zuhri (Semarang: AsySyifa', 2003), 155 . 
karakter peserta didik yang baik sebagaimana dalam kitab Ilmu wa Adab al-Alim wa al-Muta'allim yang dikutip oleh Abuddin Nata, di antaranya adalah: Peserta didik harus bersih hatinya agar mudah untuk mendapatkan pancaran ilmu dari Allah SWT., di samping itu ia juga harus mempunyai akhlak yang mulia terhadap gurunya, pandai membagi waktu, memahami tingkahlaku dalam majlis ilmu, berusaha untuk menyenangkan hati sang guru,tidak menunjukkan sikap yang memancing kemarahan guru, dan giat belajar dan sabar dalam menuntut ilmu. ${ }^{44}$ Senada dengan hal tersebut al-Ghazali juga menjelaskan beberapa sifat yang harus dimiliki oleh peserta didik agar selalu memperoleh kemanfa'atan ilmu yang dipelajarinya. Di antaranya adalah peserta didik harus bersikap tawadhu', suci jiwanya dari perbuatan-perbuatan tercela, setia dan tulus hatinya. ${ }^{45}$

Menurut Ibnu Jama'ah sebagaimana yang dikutip oleh Abuddin Nata, mengemukakan bahwa peserta didik yang baik adalah peserta didik yang mempunyai kemampuan untuk memilih, memutuskan, dan berusaha untuk belajar secara mandiri, sehingga dapat dipastikan bahwa peserta didik tersebut telah melewati masa kekanak-kanakan. Di samping itu Ibnu Jama'ah juga menekankan akan pentingnya peserta didik mematuhi perintah seorang guru. ${ }^{46}$ Senada dengan hal tersebut al-Abrasyi juga menambahkan beberapa sifat yang lain, seperti bersungguh-sungguh dan tekun dalam belajar, saling menyayangi dan rasa persaudaraan antar sesama peserta didik dan bertekad untuk terus belajar sampai akhir hayat. ${ }^{47}$

Berdasarkan sifat-sifat yang di uraikan di atas, maka dapat diketahui bahwa perhatian pendidikan Islam yang paling utama adalah agar peserta didik memiliki akhlak yang mulia. Sebab sebagai modal utama untuk mencari pengetahuan dan keberhasilan adalah Akhlak yang mulia. Dalam Islam, akhlak sangat erat kaitannya dengan pendidikan agama. Akhlak dimaknai sebagai salah satu hasil dan melekat dalam iman dan ibadat, yang bersumber pada iman dan taqwa serta mempunyai tujuan langsung yaitu keridhaan dari Allah SWT. Dengan demikian, pada hakikatnya semua ilmu itu adalah milik Allah sehingga untuk mendapatkannya kita harus mendekatkan diri kepada Allah dengan cara

44 Abuddin Nata, Perspektif Islam tentang Pola Hubungan Guru-Murid: Studi Pemikiran Tasawuf al-Ghazali, 104.

${ }^{45}$ Fathiyah Hasan Sulaiman, Sistem Pendidikan Versi al-Ghazali (Bandung: AlMa'arif, 1986), 59.

${ }^{46}$ Nata, Pemikiran Para Tokoh Pendidikan Islam, 117-118.

47 M. Athiyah al-Abrasyi, Dasar-dasar Pokok Pendidikan Islam (Jakarta: Bulan Bintang, 1993), 148. 
berakhlak mulia, dan menghindarkan diri dari akhlak yang tercela. Dengan demikian, ungkapan di atas dapat diambil benang merah bahwa ilmu itu pada hakikatnya merupakan cahaya dari Allah, dan cahaya Allah hanya akan diberikan kepada hamba-hambanya yang selalu mentaatiNya.

\section{Kesimpulan}

Potensi dasar yang dimiliki oleh setiap peserta didik tidaklah akan berkembang secara maksimal, tanpa didukung dan didorong melalui proses pendidikan. Sebab peserta didik merupakan anak yang belum mencapai taraf kematangan dan belum memiliki potensi dasar yang perlu untuk dikembangkan oleh seorang guru melalui proses pendidikan. Kebutuhan peserta didik yang harus dipenuhi di antaranya adalah (1) Kebutuhan Fisik, (2) Kebutuhan Sosial, (3) Kebutuhan untuk mendapatkan status, (4) Kebutuhan Mandiri, (5) Kebutuhan untuk berprestasi, (6) Kebutuhan ingin disayangi dan dicintai, (7) Kebutuhan untuk saling memberikan masukan, dan (8) Kebutuhan untuk beragama. Oleh karena itu, pemenuhan kebutuhan peserta didik merupakan syarat yang paling penting bagi perkembangan pribadi yang sehat untuk peserta didik. Sementara tugas peserta didik adalah sebagai berikut: Pertama, Ketika melakukan proses belajar peserta didik harus mensucikan jiwanya dari kotoran dan penyakit jiwa. Kedua, Selalu konsentrasi terhadap ilmu yang sedang dipelajarinya dan mengurangi kesibukan duniawi, Ketiga, Menuntut ilmu itu harus dilakukan secara bertahap dengan penuh kesabaran dan ketabahan. Keempat, peserta didik hendaknya mengetahui nilai ilmu yang dipelajarinya. Kelima, Selalu berusaha untuk mendapatkan ridha dari guru dan dan selalu menghormati gurunya. Di samping itu para tokoh pendidikan memberikan kriteria bahwa peserta didik yang baik di antaranya adalah: Peserta didik harus bersih hatinya agar mudah untuk mendapatkan pancaran ilmu dari Allah SWT., berakhlak mulia terhadap gurunya, pandai membagi waktu, memahami tatakrama dalam majlis ilmu, berusaha untuk menyenangkan hati sang guru, tidak menunjukkan sikap yang memancing kemarahan guru, giat belajar dan sabar dalam menuntut ilmu, harus bersikap tawadhu', mempunyai kemampuan untuk memilih, memutuskan, dan berusaha untuk belajar secara mandiri serta selalu mematuhi perintah guru, bersungguh-sungguh dan tekun dalam belajar, saling menyayangi dan rasa persaudaraan antar sesama peserta didik dan bertekad untuk terus belajar sampai akhir hayat. 


\section{Daftar Rujukan}

Abrasyi (al), M. Athiyah. Dasar-dasar Pokok Pendidikan Islam. Jakarta: Bulan Bintang, 1993.

Attas (al), Syed Muhammad Naquib. Konsep Pendidikan dalam Islam. Terj. Haidar Bagir. Bandung: Mizan, 1990.

Azis, Abd. "Humanisme dalam Pendidikan Islam: Konsepsi Pendidikan Ramah Anak". Jurnal Pendidikan Agama Islam (Journal of Islamic Education Studies), Vol. 5, No. 1 (2017).

Basri, Hasan. Filsafat Pendidikan Islam. Bandung: Pustaka Setia, 2009.

Echol, Jhon M. \& Syadily, Hasan. Kamus Inggris Indonesia. Jakarta: Gramedia, tt.

Ghazali (al), Abu Hamid. Ilmu dan Manfaatnya, Terj. Achmad Sunarto. Surabaya: Karya Agung, 2010. 2003.

Harahap, Musaddad. "Esensi Peserta Didik dalam Perspektif Pendidikan Islam". Jurnal Al-Thariqah, Vol. 1, No. 2, (Desember 2016).

Isna, Mansur, Diskursus Pendidikan Islam. Yogyakarta: Global Pustaka, 2001.

Maghfiroh, Lailatul. "Hakikat Pendidik dan Peserta Didik dalam Pendidikan Islam". MIDA : Jurnal Pendidikan Dasar Islam, Vol 2 No 2 (2019).

Nata, Abuddin, Pemikiran Para Tokoh Pendidikan Islam. Jakarta: Raja grafindo Persada, 2000.

Murid: Studi Pemikiran Tasawuf Al-Ghazali. Jakarta: Raja Grafindo Persada, 2001.

Ilmu, 1997.

Purnamasari, Nia Indah. "Komparasi Konsep Sosiokulturalisme dalam Pendidikan: Perspektif Barat dan Islam". El-Banat: Jurnal Pemikiran dan Pendidikan Islam, Vol. 9, no. 2 (2019).

Ramayulis, Ilmu Pendidikan Islam. Jakarta: Kalam Mulia, 2002. 
Ramli, M. "Hakikat Pendidik dan Peserta Didik". Tarbiyah Islamiyah, Vol. 5, No. 1, (Januari-Juni 2015).

Rasyidin, Al. Falsafah Pendidikan Islami: Membangun Kerangka Ontologi, Epistimologi, dan Aksiologi Praktik Pendidikan. Bandung: Citapustaka Media Perintis, 2012.

Rosyadi, Khoiron, Pendidikan Profetik. Yogyakarta: Pustaka Pelajar, 2004.

Rusd, Abidin Ibnu, Pemikiran Al-Ghazali Tentang Pendidikan. Yogyakarta: Pustaka Pelajar, 2009.

Thobroni, Muhammad \& Arif Mustofa, Belajar \& Pembelajaran: Pengembangan Wacana dan Praktik Pembelajaran dalam Pembangunan Nasional. Jogjakarta: Ar-Ruzz Media, 2011.

Sarwono, Sarlito W. Berkenalan dengan Aliran-aliran dan Tokoh-tokoh Psikologi. Jakarta: Bulan Bintang, 2002.

Suharto, Toto. Filsafat Pendidikan Islam. Jogjakarta: Ar-Ruzz Media, 2011.

Sulaiman, Fathiyah Hasan. Sistem Pendidikan Versi al-Ghazali. Bandung: Al-Ma'arif, 1986.

Syah, Muhibbin. Psikologi Pendidikan dengan Pendekatan Baru. Bandung: Remaja Rosda Karya, 2005.

Tafsir, Ahmad. Filsafat Pendidikan Islami: Integrasi Jasmani, rohani dan Kalbu Memanusiakan manusia. Bandung: Remaja Rosda Karya, 2010.

Uno, Hamzah B. Orientasi Baru Dalam Psikologi Pembelajaran. Jakarta: Bumi Aksara, 2010.

Wahyudi, M. Jindar. Nalar Pendidikan Qur'ani. Yogyakarta: Apeiron Philotes, 2006.

Wallace, Patricia., Goldstein, Jeffrey H., and Nathan, Peter. Introduction to Psychology. Dubuque, IA: Wm. C. Brown, 2007.

Zainuddin., dan Nasir, Mohd. Filsafat Pendidikan Islam. Bandung: Citapustaka Media Perintis, 2010. 